\title{
一般口演 1
}

\section{マウス咬筋長時間活動におけるヒスタミンの役割}

Roles of histamine in prolonged masseter muscle activity in mice

\author{
米田博行 ${ }^{1,2)}$, 土谷昌広 ${ }^{3)}$, 八百板 (新島) 富紀枝 ${ }^{4)}$, 佐々木啓一 ${ }^{1)}$ \\ 渡邊 誠 $^{3)}$, 菅原俊二 ${ }^{2)}$, 遠藤康男 ${ }^{2)}$ \\ Hiroyuki Yoneda $^{1,2)}$, Masahiro Tsuchiya ${ }^{3)}$, Fukie Niijima-Yaoita ${ }^{4)}$, Keiichi Sasaki ${ }^{1)}$ \\ Makoto Watanabe $^{3)}$, Shunji Sugawara ${ }^{2)}$, Yasuo Endo ${ }^{2)}$ \\ ${ }^{1)}$ 東北大学大学院歯学研究科口腔システム補緅学分野 \\ ${ }^{2)}$ 東北大学大学院歯学研究科口腔分子制御学分野 \\ ${ }^{3}$ 東北大学大学院歯学研究科加齢歯科学分野 \\ 4) 東北薬科大学薬理学講座 \\ ${ }^{1)}$ Division of Advanced Prosthetic Dentistry, Tohoku University Graduate School of Dentistry \\ ${ }^{2)}$ Division of oral molecular Regulation, Tohoku University Graduate School of Dentistry \\ ${ }^{3)}$ Aging and Geriatric Dentistry, Tohoku University Graduate School of Dentistry \\ ${ }^{4)}$ Department of Pharmacology, Tohoku Pharmaceutical University
}

\section{I. 目的}

咬筋の痛みと硬直は顎関節症（TMD）の主要な症状 であり，原因として歯ぎしりや長時間の食いしばり等が 考えられている。長時間の筋肉活動には筋肉微小循環の 機能維持が必要と考えられる。 ヒスタミン $(\mathrm{H})$ は炎症 に打ける微小循環調節因子であり，発痛物質でもある。 私達は chlorpheniramine（中枢一未梢性 H1 受容体拮抗 薬）が TMD に有効であることを以前報告した ${ }^{1)}$. H は その貯蔵部位からの遊離または histidine decarboxylase (HDC) の誘導による新たな産生により供給される。 IL-1 は顎関節症に関連する炎症性サイトカインと考えら れているが (患者関節液に検出), 筋肉も含め種々の組 織で強力な HDC 誘導作用をもつ ${ }^{1,2)}$. 私達はマウス咬筋 の長時間活動に扔ける H・HDC・IL-1の役割を検討した。

\section{II. 方 法}

実験には，7 から 8 週齢の BALC/a マウス, HDC-KO マウス，H1受容体 KO マウス（コントロールにC57BL/ 6), マスト細胞を欠損する $\mathrm{W} / \mathrm{W}^{\mathrm{V}}$ マウス（コントロー ルに+/+マウス）を用い，以下について検討した.

\section{1．咬筋の運動}

マウスを細い筒に閉じ込め $(\mathrm{R}$ : restraint $)$ 出口をプ ラスチック板で閉じると, マウスは脱走用の隙間を作 るため，この板を自発的に長時間咬み砕き続ける $(\mathrm{G}$ : gnawing）（これを $\mathrm{R}+\mathrm{G}+$ と呼称）。この板の減少量を咬 筋運動量とした ${ }^{3)}$ (図 1 )。尾をテープで筒に固定しマウ スがプラスチック板に届かない様にした場合 $\left(\mathrm{R}+\mathrm{G}^{-}\right)$ と，ケージに入れた通常の場合 $\left(\mathrm{R}^{-} \mathrm{G}^{-}\right)$をコントロー ルとした。

この実験系を用いて, 各種マウスでの咬筋運動量の比 較を行うと共に, H1 受容体拮抗薬である Fexofenadine $(40 \mathrm{mg} / \mathrm{kg})$ ）(末梢性 $\mathrm{H} 1$ 受容体拮抗薬), pyrilamine (24 $\mathrm{mg} / \mathrm{kg}$ ) (中枢一未梢性 H1 受容体拮抗薬）の投与によ る検討も行った。また， $\mathrm{R}+\mathrm{G}+$ 後の咬筋，胸筋，大腿四 頭筋を採取し，realtime PCRによるHDC mRNAの測 定, HDC 活性の測定 ${ }^{2)}$, 及びトルイジンブルー染色に よる組織学的検討を行った.

\section{2. 大腿四頭筋の運動}

強制歩行実験（図 2$)^{4)}$ を行い，実験スタート時のマ ウスの数に対する脱落せずに残っているマウスの割合 を持久力として比較し，また，運動後の大腿四頭筋の HDC 活性を測定した. 


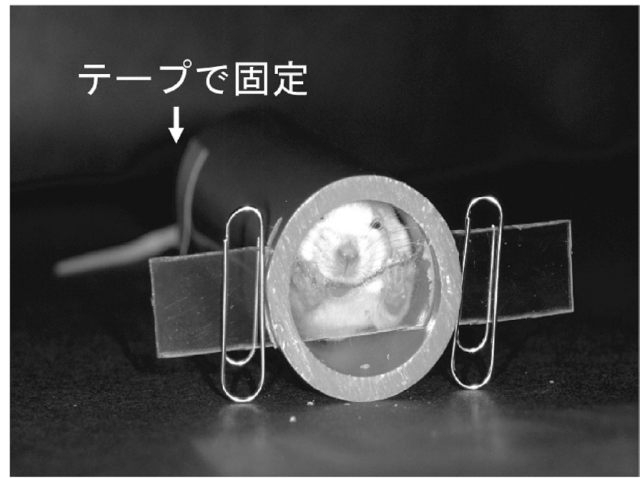

円筒 $\phi: 2.5 \mathrm{~cm}$, 長さ : $10 \mathrm{~cm}$

図 1 咬筋運動の測定

\section{3．筋肉でのIL-1 による HDC 誘導}

IL-1 $(20 \mu \mathrm{g} / \mathrm{kg})$ を腹腔注射し， 4 時間後の HDC 活 性を調べた。

\section{III. 結果及び考察}

\section{1. 咬筋での結果}

Fexofenadine を投与した群では咬筋運動量が減少し, pyrilamine 投与群においても減少傾向を示した（有意 差なし). H1 受容体 KO マウスと HDC-KO マウスの咬 筋運動量は対照マウスよりも低值を示した。このこと から $\mathrm{H}$ は咬筋の長時間活動の維持に関与することが示 唆された. また, $\mathrm{R}+\mathrm{G}+$ 後の咬筋での HDC mRNA と HDC 活性はいずれもコントロールに比べ, 高い值を示 した。一方，W/Wv マウスを用いた実験では，前記結 果より $\mathrm{R}+\mathrm{G}+$ で $\mathrm{W} / \mathrm{W}^{\mathrm{v}}$ マウスの咬筋運動量は, +/+マ ウスとの比較において低くなると予想したが，意外にも 両者の間に有意差は見られなかった。しかし， R+G+に よる $\mathrm{HDC}$ 誘導は，W/W $\mathrm{W}$ マウスでは僅かであった。咬 筋のトルイジンブルー染色では, $\mathrm{BALB} / \mathrm{c}$ と +/+ マウ スでは，筋外膜の血管／神経周囲にマスト細胞が見られ たのに対し，W/Wv マウスではマスト細胞は検出されな かった。

\section{2. 大腿四頭筋での結果}

$\mathrm{W} / \mathrm{W}^{\mathrm{v}}$ マウスの持久力は+/+マウスよりも低く, 強 制歩行後の大腿四頭筋での HDC 誘導も W/Wv マウスで は僅かであった。

\section{IL-1 による HDC 誘導}

IL-1の腹腔投与は，+/+ マウスの咬筋と大腿四頭筋に

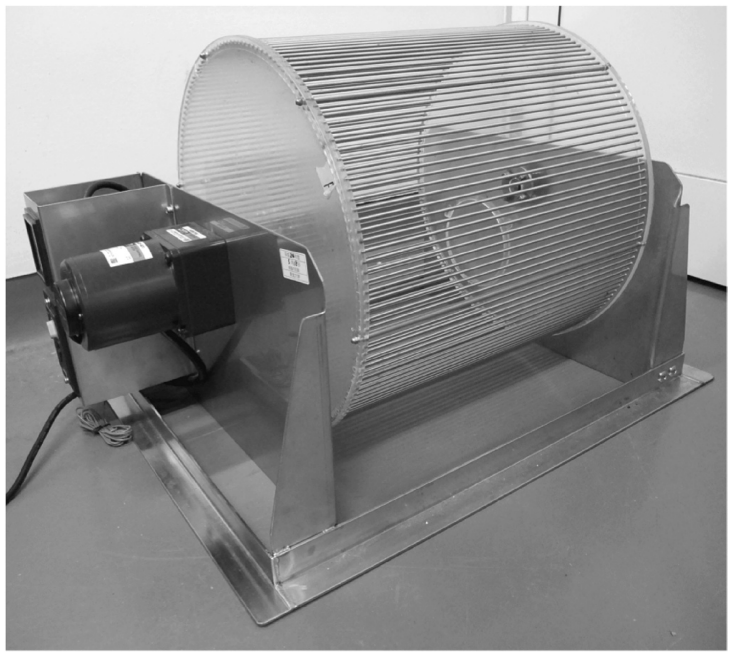

図 2 強制長時間歩行実験装置

HDC を顕著に誘導したが，W/Wv マウスでの誘導は僅 かであった。

以上の結果は以下を示唆する。長時間運動にはマスト 細胞由来のヒスタミンと HDCの誘導が関与し，ヒスタ ミンは末梢組織の H1 受容体を介して筋肉の長時間運動 の維持に関与するものと思われる。末梢性 H1 受容体拮 抗薬は咬筋の過労を予防し，ブラキシズムや TMDの予 防に有効であることを示唆した。

\section{N. 文献}

1) Watanabe et al. 1999. Possible involvement of histamine in muscular fatigue in temporomandibular disorders: animal and human studies. J Dent Res 78: 769-775.

2 ) Endo Y. 1989. Induction of histidine and ornithine decarboxylase activities in mouse tissues by recombinant interleukin-1 and tumor necrosis factor. Biochem Pharmacol 38: 1287-1292

3 ) Ayada et al. 2002. Gnawing behavior of a mouse in a narrow cylinder: a simple system for the study of muscle activity, fatigue, and stress. Physiol Behav 77: 161-166

4 ) Niijima-Yaoita et al. 2012. Roles of histamine in exercise-induced fatigue: favouring endurance and protecting against exhaustion. Biol Pharm Bull 35: 91-97. 